\title{
A STRATÉGIAI TERVEZÉSTŐL A STRATÉGIAI MENEDZSMENTIG
}

\author{
A KÖZGÁZ ESETEI AZ INTEGRÁCIÓVAL
}

Jelen tanulmány a „Közgáz" integrációs eseteinek a bemutatásával és elemzésével kívánja alátámasztani a stratégiai menedzsment azon alaptételét, amely szerint nem elég jó stratégiát alkotni, de legalább ilyen, ha nem fontosabb, a megvalósítás szervezeti, személyi, motivációs és kulturális hátterének megfelelő kialakítása.

A szerző négy esetet (Közgáz - Budapesti Műszaki Egyetem, Közgáz - Eötvös Lóránd Tudományegyetem, Közgáz - Államigazgatási Főiskola, Budapesti Közgazdaságtudományi és Államigazgatási Egyetem - Kertészeti és Élelmiszertudományi Egyetem) mutat be szisztematikusan vizsgálva a környezeti tényezőket, a víziót, a támogató személyi és szervezeti struktúrát, a meglévő érdekcsoportok motivációját, valamint a támogató vagy elutasító szervezeti kultúrát. Amint az a ma már mindenki által ismert végeredményből (2015. január 2-tól ismét háromkarú egyetemként működik a "Közgáz") egyértelműen levezethető az integrációs kísérletek, vagy a valóban létrejött integrációk önmagukban sikerteleneknek tekinthetők. Az okok mélyebb elemzése hasznos tanulságként szolgálhat bármely szervezet és annak vezetése számára.

Kulcsszavak: stratégia, stratégiai menedzsment, felsőoktatás, integráció, Közgáz

$E^{n}$ anulmány címének első része régi, mondhatnánk ,szakállas" témát sejtet. A stratégiai tervezés elméleti keretei, vagy, ha úgy tetszik, elméletté formálódása a múlt század 60-as éveire tehető (Tari, 1996; Taylor, 1986; Bathia, 2014; O’Shanassy, 1999; Grant, 2008). Chandler, Ansoff, valamint a „Harvard iskola” alapítóinak munkásságához köthető leginkább az addig felhalmozott tudományos és empirikus kutatási eredmények rendszerbe foglalása, elméletté formálása. ${ }^{1}$ Maguk a kutatók is viszonylag gyorsan szembetalálkoztak azonban az olyan jelenségekkel, mint a stratégiák egy jelentős részének sikertelen megvalósulása. Kapcsolódó empirikus tapasztalatként jelentettek gondolkodási feladványt a hasonló stratégiával eltérő, illetve különböző stratégiával hasonló teljesítményt nyújtó vállalatok. Visszaemlékezések szerint maga Ansoff ,teszi fel a kérdést”, hogy valójában a stratégiai tervezés egy rossz teória, vagy még egy be nem fejezett valami, ami fejlesztésre szorul. Válasza, hogy a tervezés csak egyik pillér, de kell egy másik is, mégpedig az a képesség, amely az írásos tervet piaci realitásokká konvertálja. Ennek szellemében használja a stratégiai menedzsment kifejezést 1973-ban egy konferencián, a Vanderbilt Egytemen (Tari, 1996; Bhatia, 2014). A világ természetesen nem haladt olyan gyorsan, hiszen, amint azt egy évfordulós Long Range Planning tanulmányból megtudjuk, nemhogy a stratégiai menedzsment kategória nem vált még a 70-es években általánossá, de maga a „stratégia (strategy)”, mint kulcsszó is csak 1983 környékén „elözte le” a tervezést (planning) a hivatkozott folyóirat absztraktjaiban (Cumings, et al., 2009)². Történt mindez annak ellenére, hogy ezek, vagy már a megelőző évek produkáltak olyan, máig is érvényes tételeket, mint pl. a szándékolt és megvalósított stratégiák különbsége és a kettő között létező folyamat (Mintzberg, 1998), alapoztak meg, vagy alakítottak ki mind a mai napig a stratégiai menedzsment paradigmáinak tekinthető elméleteket, mint az erőforrás-alapú közelítés (Teece, 1980; Rumelt, 1984), vagy a versenyelöny iparági elemzésre épülő modellje (Porter, 1980).
A következő évtizedek szakirodalma egyre inkább a stratégiai menedzsment rendszerét, annak filozófiáját, eszközeit, a vállalati teljesítménnyel összefüggö kérdéseit tekintette, tekinti a kutatások és a vállalati gyakorlat központi elemének. Az már nem igazán kérdés ezekben a munkákban, hogy mi a viszony a vállalati jövőalkotás e két alapkategóriája között. Számtalan empirikus kutatás is bizonyította, hogy gyorsan változó világunkra a hiperversenyre nem, vagy nemcsak a stratégiai tervezés, de még inkább annak menedzselési képessége, azon belül is a változásokra való reagálás gyorsasága, az innovációs és kockázatkezelési képesség magas színvonala az adekvát válasz. Nem ritka azon vélemény, amely már magát a stratégiai menedzsment rendszerét is túlhaladottnak tekinti, új, domináns elmélet formálódását (Hermann, 2005), vagy már elfogadottságát (Bhatia, 2014; O’Shanassy, 1999) fogalmazza meg. Meg kell itt jegyezni, hogy a stratégiakutatások „nagy öregjei”, miközben felhívják fontos és jelentős változásokra a figyelmet, ezeket a stratégiai menedzsment keretein belül és nem egy új paradigmához kötődve jelenítik meg (Porter, 2001, 2006, 2007, 2011; Grant, 2008; Mintzberg, 1998). Ugyanezt tapasztaljuk a több évtizeddel ezelőtt kialakított paradigmák egyes tételei kritikusainál (McGrath, 2013), vagy a paradigmák továbbfejlesztésével, kombinált alkalmazásával foglalkozó tanulmányok esetében is (Spanos et al., 2001; Lapersonne et al., 2015). Visszatérve a stratégiai tervezés és menedzsment különbségeire és elválaszthatatlanságára kijelenthetjük, hogy bár mindezt tudjuk és hangsúlyozzuk, mégis sok-sok példával találkozhatunk, amelyben a kudarc tetten érhető oka a ,jó öreg” stratégiai menedzsment téziseinek figyelmen kívül hagyása.

Jelen tanulmány a „Közgáz” integrációs eseteinek bemutatásával és elemzésével e megállapítást kívánja alátámasztani. Megírásában motivált a több évtizedes oktatási tapasztalat, amelynek során mindig is igyekeztem gyakorlati példával elmagyarázni a hallgatóságnak, hogy hogyan 
is függ össze a stratégiai tervezés és stratégiai menedzsment rendszere. A példákat egy idő után a Közgáz integrációs kudarcaiban találtam meg, amelyeknek én is részese voltam több évtizedes, különböző szintű vezetői munkám során. Az elsősorban az üzleti világra szabott témakörnek felsőoktatási intézményekre való adaptálását feltétlenül bátorította az általam igen tisztelt Henry Mintzberg és szerzőtársa (2003) által megírt cikk, amely az alábbi címet viseli: Stratégiai menedzsment fejjel lefelé: Stratégiák nyomon követése a McGill Egyetemen 1829-től 1980-ig. Amíg ugyan a szerzők a világhírű egyetem „első” 150 évében keresik a stratégiát, az állandóságot és a változást, addig a mi esetünk „,csak” két évtizedet ölel fel. Ez a két évtized azonban, horderejében - mondhatjuk - stratégiai változásokat hozott a magyar felsőoktatásban, melyek eredményei csak hosszú távon mérhetők. Hogy mik és hogyan történtek, arról kiváló elemzéseket találunk Barakonyi (2009), Polonyi (2015), Hrubos (2013), Temesi (2012), Berács (2017) munkáiban, amelyek kiegészítették, vagy/és megerősítették egyéni tapasztalataimat.

\section{„Elméleti keretek és kutatásmódszertan”}

Induljunk ki a stratégiai menedzsment alábbi definíciójából: „Stratégiai menedzsment: a stratégiai tervezés, a stratégiamegvalósítás és a visszacsatolás integrált egységére épülő vállalatvezetés" (Chikán, 2008, p. 506.) .

Amint azt majd meglátjuk, a Közgáz eseteinél e meghatározás minden eleme hangsúlyt kap, legeröteljesebben azonban a megvalósításra, mint a stratégiai menedzsment immanens alkotóelemére hívom fel a figyelmet. Nemcsak azért, mert a különbözö tervekből siker, vagy hasonló tervekből siker, vagy kudarc „,rejtélyének” kulcsa a megvalósítás különbségében találtatott meg, és ez a „felfedezés” átvezette az elméletet a stratégiai tervezés rendszeréből a stratégiai menedzsmentébe, hanem azért is, mert a megvalósíthatóság figyelmen kívül hagyása, és/vagy a megvalósítás gyengeségei vezettek jórészt eseteinkben is a végső kudarcokhoz. Ahhoz természetesen, hogy a Közgáz integrációs kísérleteit és eredményeit elemezni tudjuk, azokról a stratégiai menedzsment elméletének felhasználásával értékítéletet tudjunk mondani, nem kerülhetjük meg az adott kísérletek (stratégiák) készítésének környezeti feltételeit, az állam és a felsőoktatási intézmények viszonyát, az autonómia, a költségvetési gazdálkodás kérdéseit. A stratégiamegvalósítás, vagy -megvalósíthatóság szempontjából fontos, esetenként meghatározó szerepe van olyan belső tényezőknek, mint a legfelső vezetés elkötelezettsége, meggyőző, motiváló képessége, a stakeholderek, az egyetemi érdekcsoportok létezése, alkuereje, a belső hatalmi viszonyok.

Tovább bonyolítja a helyzetet, hogy az ún. érintetti kör, az integrációban részt vevő minden (de minimum két) intézménynél létezik, adott esetben különböző érdekektől vezérelve. Példával élve a fuzionálást megcélzó egyetemek hallgatósága bizonyos szempontok szerint azonos „státusúnak" tekinthető, érdekeik az integrációt illetően azonban nagyon is eltérhetnek egymásétól. Márpedig az érdekek felismerése, a stratégia elfogadása, majd annak megvalósítása irányába történő motiválás a stratégiai menedzsmentnek a vezetői vízión és irányítási képességen túl a másik fontos eleme. Ebbe a körbe sorolandók az érintett szervezetek és szervezeti kultúrák. Nem, vagy nem elsősorban a formális szervezeti hierarchiáról van szó, sokkal inkább a döntési folyamatokról, amelyek során artikulálódhatnak a szervezetek érdekei, informális személyek, csoportok kerülhetnek befolyásoló pozícióba. Külön izgalmas kérdés témánk szempontjából maga a stratégiaalkotás szervezete, hiszen a széles körű részvétel motivál, a folyamat során lehetőséget nyújt az álláspontok ütközésére. Mindemellett a vezetés számára világossá válhat a támogatói és ellenzői kör, a belső szövetségesek, akikkel a célokat realizálni lehet.

A szervezeti kultúra részben adott intézményen belül fejti ki hatását, másrészt az intézmények között jelenthet vonzeröt, vagy okozhat ellenállást. A merev, hierarchikus viszonyok, a túlzott tekintélytisztelet, szemben a liberálisabb, lazább, partneri viszonyokra épülö hallgató-oktató kapcsolattal például igencsak befolyásolhatja a résztvevők támogatását vagy elutasítását.

Az elméleti keretek közé kívánkozik a konkrét esetek megalapozásaként, hogy az előzőekben a stratégiai menedzsment rendszerében többször is azonos módon kezeltem a stratégia megvalósítását a stratégia megvalósíthatóságával. Amennyiben ugyanis a stratégiai tervet nem fogadják el, vagyis az integráció nem jön létre, nem beszélhetünk megvalósításról. Magát az eredményt viszont elemezhetjük a stratégiai menedzsment szemszögéből, vagyis, hogy sikerült-e a tervezési és a végső döntési folyamat során a legfőbb cél, az integráció támogatását megszerezni. Részben összefoglalva az eddigieket, részben formalizálva az esetek elemzésének kereteit - tegyük fel a fontos kérdéseket, hogy vajon beszélhetünk-e:

- a környezetnek a felsőoktatás átalakítására irányuló nyomásáról,

- felsővezetői vízióról és a stratégiát levezénylő képességről,

- olyan szervezeti megoldásokról és kapcsolódó személyi háttérről, amely mind a tervezés, mind a megvalósítás során a cél elérését támogatja,

- az érdekcsoportok megfelelő motivációjáról a stratégia elfogadása és megvalósítása érdekében,

- olyan szervezeti kultúráról, jellemzőkről, müködési módokról, amelyek a potenciális partnerek, vagyis a tervezett fúzióban részt vevő intézmény(ek) részéről vonzerőt jelentenek és nem ellenálláshoz, ellenstratégia kialakításához vezetnek.

A kutatás módszertanát röviden és leegyszerüsítve viszszaemlékezésnek lehet tekinteni. A szerző személyesen vett részt az integrációs folyamatokban, aktívan közremüködött az elökészítésben és a döntéshozatalban, átélte a szándékolt, nem elfogadott és nem megvalósított stratégiák élményeit éppúgy, mint a szándékolt és realizált stratégiák közötti különbségeket. Ezek a stratégiák nem informális folyamatok termékei voltak. A munka rangos egyetemi személyiségekből álló bizottságokban folyt, míg a jóváhagyási procedúra a hagyományos fórumok, testü- 
letek hatáskörébe tartozott. A több eset közül az egyikben az akkori „Big Five” tanácsadó cégek közül a PricewaterhouseCooperst is bevonták. A folyamatok formális, magyar és angol nyelvü stratégiai tervekkel és egyéb dokumentációval zárultak. A ,visszaemlékezés” mögött tehát komoly, ha aktuálisan nem is felújított stratégiaalkotási lépéssor és tervek állnak.

\section{Miért éppen integráció és miért éppen Közgáz?}

Az 1989-90-es rendszerváltás mindent átalakítani kívánó folyamataiból a felsőoktatás sem maradt ki. A nagy költségvetési alrendszerek átvilágítására és fejlesztésére „hivatott" szervezetek között hamarosan megjelent a Világbank és az IMF, mint potenciális hitelező. Munkatársaik, tanácsadóik a magyar felsőoktatás alacsony hatékonyságát a valamikori szovjet rendszertől ,örökölt”, szakegyetemi struktúrából fakadó széttagoltságra vezették vissza. Ebből értelemszerüen következett az egyik legfontosabb fejlesztési javaslatuk bizonyos intézménycsoportok integrációjára, tudományosan alátámasztva, „universitások” létrehozására és természetesen az ehhez tapadó szervezeti, irányítási, költségvetési stb. stratégiai lépések megtételére. Fontos mozzanata volt a felajánlott együttmüködésnek az előkészítésre és megvalósításra vonatkozó finanszírozási hajlandóság. A javaslatot a különböző színezetű kormányzatok is támogatták. Adott tehát a legfontosabb stratégiai cél, amely mögött, motivációként felsejlik a forrásszerzési lehetőség, a leépítésekkel, megszorításokkal átélt időszakokban. Ebben az egész kontextusban, a rendszerváltás utáni negyedszázadban a „Közgáz”³-nak különleges szerep jutott, nagyrészt az integrációhoz kapcsolódóan.

Az 1948-ban önálló egyetemként megalapított Magyar Közgazdaságtudományi Egyetem 1953-ban „kapta” a Marx Károly elnevezést. 1990-ben vette fel a Budapesti Közgazdaságtudományi Egyetem nevet mind a mai napig meglévő három alapkarral ${ }^{4}$ (mai elnevezésben: Gazdálkodástudományi, Közgazdaságtudományi, Társadalomtudományi).

Ezt követően a „Közgáz esete az integrációval” a következőképpen alakult:

1996 Stratégia a Budapesti Müszaki Egyetemmel való egyesülésről,

BME részéről megszavazva, Közgáz részéről elutasítva.

1997-1998 Stratégia az Eötvös Lóránd Tudományegyetemmel való fúzióra,

ELTE részéről megszavazva, Közgáz részéről leszavazva.

2000 Kormányzati döntés az Államigazgatási Főiskola (ÁIF) Közgázhoz csatolásáról. Létrejön a 4 karú Budapesti Közgazdaságtudományi és Államigazgatási Egyetem.

2003 Az intézmények saját kezdeményezésére egyesül a Közgáz, valamint a Szent István Egyetemből kiváló, egykori Kertészeti- és Élelmiszertudományi Egyetem (KEE), és 2004 szeptemberében az új, hét karú intézmény felveszi a Budapesti Corvinus Egyetem nevet.

2011 Kormányzati (majd parlamenti) döntés az új, Nemzeti Közszolgálati Egyetem létrehozásáról és ezzel együtt a Corvinus Közigazgatástudományi (korábban Államigazgatási) Kara elcsatolásáról.

2015 Kormányzati döntés az egykori Kertészeti Egyetem három karának a leválasztásáról és a Szent István Egyetemhez történő visszacsatolásáról. A kör bezárul, ismét a három karú Közgáz stratégiája került napirendre a 2016. július elsejével hivatalba lépő új rektor feladataként.

A kérdésre tehát, hogy „miért a Közgáz?” - túl a szubjektív okokon az a válasz, hogy azért, mert a Közgázzal a témát figyelembe véve szinte minden megtörtént. Beszélhetünk önkéntes kezdeményezésekröl és elvetélt stratégiákról, külső és belső döntésekről, nem realizált megvalósulásról és a viszonylag ritkább, minden esetben egyetemen kívüli hatáskörben eldőlt dezintegrációkról is. A nem hivatalos, de hazai viszonyok között évtizedek óta elfogadott „Közgáz” név használata mellett még, olyan praktikus ok is felsorakoztatható, hogy e tanulmányban nem szükséges rendre magyarázni, hogy a mai Budapesti Corvinus Egyetemnek melyik elődintézményéről van szó az adott összefüggésben.

A folyamatok, döntések és azok megvalósulása kiválóan elemezhetö és beilleszthető a stratégiai tervezés és stratégiai menedzsment gondolatvilágába. Különösen így van ez, az ún. önálló kezdeményezésű integrációs stratégiákkal, hiszen valódi intézményi célokról és elképzelésekről ezek esetében beszélhetünk. A felsoroltak közül nem tartozik ezek közé az Államigazgatási Főiskola integrálása, de néhány tanulságával azért érdemes foglalkozni. A dezintegrációs döntések és megvalósításuk azonban a végeredményt kivéve már kívül esnek elemzésünk terén.

\section{A négy integrációs eset a stratégiai menedzsment szemszögéből}

Az 1. táblázat mintegy vázlatát, legfontosabb mozzanatait tartalmazza a Közgáz eseteinek, amelyek részletes kutatása sok-sok tanulságul szolgálhat mind a stratégiai menedzsment, mind a felsőoktatás-irányítás (fenntartói és egyetemvezetői egyaránt) részére.

\section{„Hozzunk létre egy kelet-európai MIT-t! A Közgáz-BME esete 1996}

E kicsit nagyképű vízió soha nem került nyilvános deklarálásra, de az integrációs stratégia lelkes kidolgozóiban ott motoszkált. A környezet, a körülmények is ,kedveztek” egy „régi-új”s egyetem létrehozásának.

A már említett világbanki javaslatok és a hozzájuk kapcsolódó többletfinanszírozási forráslehetőségek hatására az 1990-es évek közepén, önkéntes szerveződésként létrejött a Budapesti Egyetemi Szövetség (BESZ), amelynek tagjai voltak: Államigazgatási Főiskola (ÁIF), 
A Közgáz esetei a stratégiai menedzsment szemszögéből

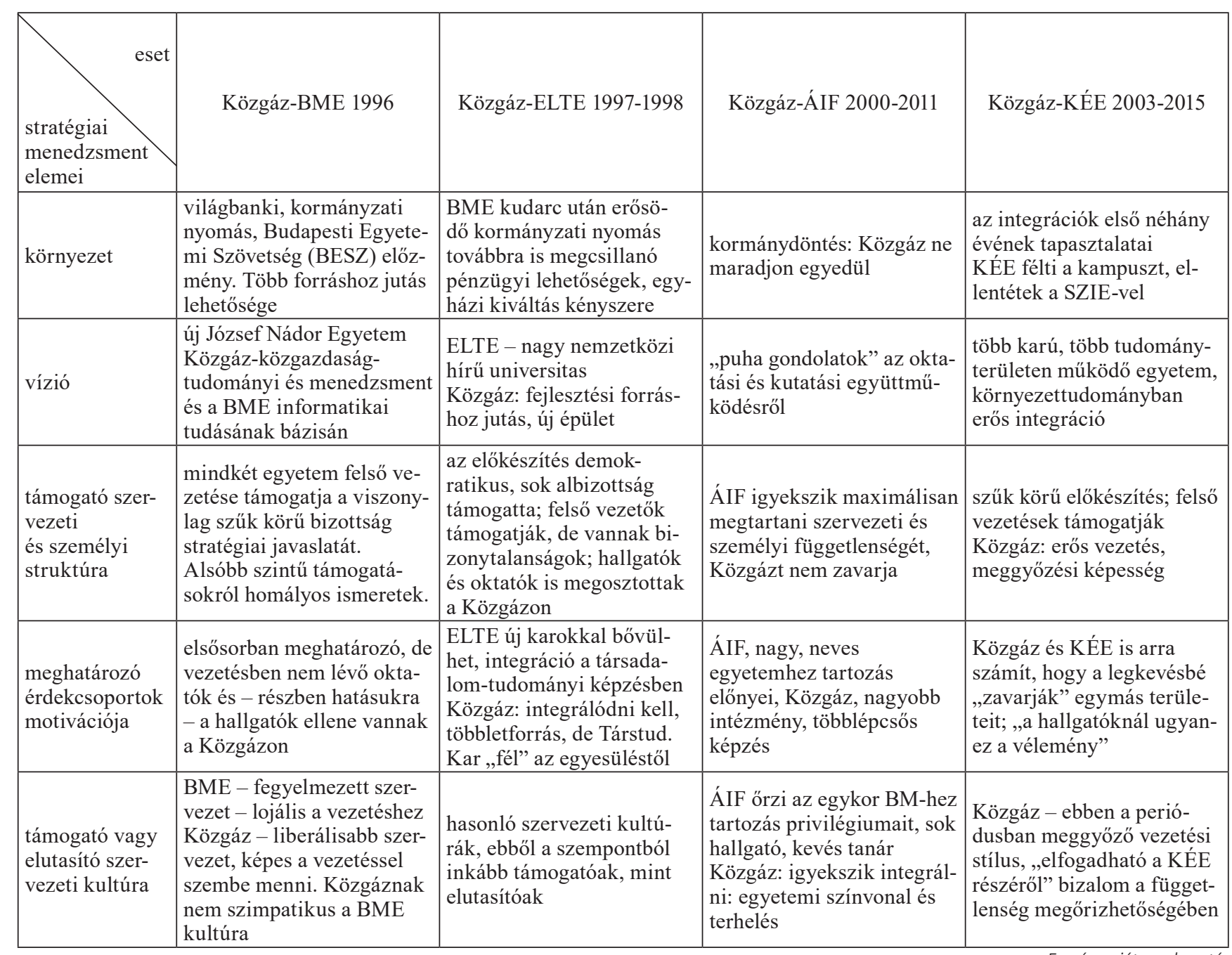

Állatorvostudományi Egyetem (ÁOE), Budapesti Közgazdaságtudományi Egyetem (BKE), Budapesti Müszaki Egyetem (BME), valamint a Kertészeti és Élelmiszertudományi Egyetem (KÉE).

Az egyesülés típusú szervezet jogilag is bejegyzést nyert és megalakultak irányító testületei. Deklarált célja, különböző típusú - elsősorban oktatási - együttműködés és technikai-infrastrukturális hátterének (pl. közös telefonhálózat) megteremtése, valamint forrásszerzés intézményközi és intézményeken belüli fejlesztésekre (Felsőoktatási Fejlesztési Alap - FEFA- projektek). A BESZT-t többen is egy nagy, integrált egyetem előszobájának tekintették, amelyen keresztül haladva el lehet jutni közös diploma kiadásáig is. Ennek a törvényes keretei azonban nem voltak adottak (föleg úgy, hogy mindenki megőrzi az önállóságát), így a nagy tervekből mindössze néhány oktató meghívása valósult meg.

Egy másik jelentős tényezőnek a „Bokros-csomag” utáni állapot tekinthető, amely leépítéseket eredményezett a legtöbb intézménynél (leginkább a BME hajtotta végre), amelyek (legalábbis vezetői szinten) kiutat láttak az integrációban.
Nem hagyható figyelmen kívül a BESZ-ben lévő két nagy egyetem a BME és a BKE iránti hallgatói érdeklődés. A mérnöki szakma iránti kereslet és ennek megfelelően a Budapesti Müszaki Egyetemre való jelentkezések száma a 90-es évek közepén csökkenő tendenciát mutatott, a hallgatói létszám a lehetséges kapacitás alá került. Ezzel szemben a Közgáz élvezte a piacgazdaságra való átállás előnyeit, ami az üzleti képzés iránt ugrásszerűen megnövekedett igényben manifesztálódott. Itt jegyezzük meg, hogy különböző indokkal és különböző időpontokban a szövetségben együttműködő intézmények egyik része (AIF, ÁOE, KÉE) „kiszállt” a valódi integrációra vonatkozó döntési folyamatokból.

Az egykori József Nádor Egyetem „résztvevői”-nek aktuális vezetése egy, a BME informatikai tudására és a Közgáz közgazdasági és menedzsment oktatási és kutatási tapasztalataira épülö felsőoktatási intézményt vizionált, amely tartósan vonzerőt jelent a jelentkezők irányába. ${ }^{6}$

E megállapításból is következik, hogy mindkét egyetem felső vezetése (rektor, rektorhelyettesek részben, vagy teljes körüen a dékánok) egyetértett a viszonylag szük körü, rektorhelyettesek által vezetett bizottság stratégiai 
javaslataival. Az alsóbb vezetési szintekről és főleg az egyetemi tanácsban egyharmad arányban jelen lévő hallgatók ellenkező álláspontjáról a BME-ről nem érkeztek hírek. A Közgáz esetében a tanári kar megosztott volt, a hallgatók pedig nyilvános tiltakozásuknak adtak hangot, vagyis korántsem beszélhettünk egységes, támogató szervezeti-személyi struktúráról.

Ez egyben azt is jelentette, hogy a stratégiaalkotásban és -megvalósításban oly fontos érintetti csoportok - nyílván érdekeikre visszavezethetően - eltérően ítélték meg az integráció lehetséges következményeit. Az integráció mellett volt az oktatásirányítás és a Közgáz felső vezetése, megosztottak az oktatók (munkavállalók) és ellene a hallgatók.7 Itt érdemes megjegyezni, hogy a Közgáz vezetése az abban az időben kulmináló egyházi kiváltás (Lónyay Gimnázium visszaadása és helyettesítése) megoldásának lehetőségét is látta az integrációban, együtt az új típusú, a piacgazdaság elméletére épülő tananyagrendszer kidolgozásának finanszírozásával. A BME elsősorban hallgatói érdeklődésnövekedést, a kapacitás kihasználását és szintén fejlesztési (nem épület, hiszen az elmaradt világkiállítás épületeiből részesült) forrásokhoz való hozzájutást, mint motiváló tényezőket tervezett.

Érdemes a Közgáz ellenzőinek véleményét, amelyet explicit módon és nyilvánosan is megfogalmaztak a hallgatók, bemutatni. Az összehívott hallgatói gyűlésen két alapvető dolog hangzott el:

- az integráció a jól és hasznosan kombinálható müszaki-közgazdasági-menedzsment tudás miatt egy sor vonzó munkakör megpályázása esetén az azokkal rendelkező mérnököket juttatja versenyelőnyhöz, szemben a „,csak” közgazdasági-menedzsment diplomával rendelkezőkkel,

- nem kívánunk a „feudális típusú” BME hallgatói lenni.

Ez utóbbi megjegyzés már a szervezeti kultúra megítélését is jelenti. A Közgáz liberális szellemisége, a vezető-oktató, oktató-hallgató viszony nem igazán merev keretei és gyakorlata erősen szemben áll egy hierarchikusabb-bürokratikusabb rendszerrel, lehetne talán egy kissé magyarázni ezt a nem igazán megélt, de szájhagyomány útján generációról generációra átöröklödő álláspontot. Van azonban a szervezeti kultúrának egy, részben az előbbihez tapadó jellemzője a fegyelmezett lojalitás, vagy az egyetemi demokráciára hivatkozó ellenvélemény képviselete. Az első, az egész előkészítési és döntési folyamatban érzékelhető volt a BME részéről, ami alapvetően magyarázza az emlékezetem szerint - egyhangú szavazási végeredményt. Ezzel szemben a Közgáz testülete viszonylag magabiztosan szavazta le az integrációt. Azt a titkos szavazás ellenére is sejteni lehetett, hogy a hallgatói képviselet egyhangú nemmel voksolt.

Kijelenthetjük ezek után, hogy a Közgáz és a BME vezetése által kidolgozott integrációs stratégia a Közgáz stratégiája szempontjából elbukott. Fogalmazhatunk úgy is, hogy nyert az ellenzői tábor, az ő - ha nem is formális - stratégiájuk sikeresebbnek bizonyult.
Kicsit az eset összefoglalójaként is érdemes rögzíteni, hogy bár a folyamat nem jutott el a stratégia megvalósítási fázisába már a döntés elökészítésben is tetten érhetők voltak a stratégiai menedzsment legfontosabb elemeinek hiányosságai. A viszonylag kedvező környezeti feltételek, a talán megfelelőnek értékelhető vízió és stratégia mellett nem beszélhettünk támogató szervezeti és személyi feltételekről, a vízió irányába mutató érdekek elfogadásáról és a vezetéshez lojális szervezeti kultúráról. A tényekhez hozzátartozik az is, hogy az akkori Közgáz vezetése, amely valóban a demokratizmust és a bevonó vezetést tartotta szem előtt, bízva e stílus „,népszerüségében”, bár érezte a helyzetet, mégsem tett meg mindent a nem támogatók meggyőzésére. Ezzel szintén egy, a stratégiai menedzsment nélkülözhetetlen eszközéről mondott le.

\section{Cél: egy nagy, nemzetközi szintű universitas létrehozása. Közgáz-ELTE esete 1997-1998}

A BME-Közgáz integráció kudarca és a kormány változatlan integrációs stratégiája, mint környezeti összetevők a korábbinál is erősebb nyomás alá helyezte a Közgázt (de általában a magyar felsőoktatást is). Továbbra is érvényben volt az az álláspont, hogy jelentős fejlesztési forráshoz csakis szervezeti integráció révén lehet hozzájutni. A Közgáz számára is egyre inkább létkérdéssé vált az egyházi kiváltás ügye, hiszen a döntések a Lónyay Gimnázium visszaadásáról megszülettek, az ellentételezés módja, helye nem igazán körvonalazódott. A ,kárpótlás” összegét egy 1993-as számításokra épülő, 1994-es kormányrendelet határozta meg, amely a magas infláció miatt folyamatosan értékét vesztette, költségvetési többletforrásra pedig abban az időszakban alig volt remény. Ezért lett volna fontos egy nagyösszegű pályázat megnyerése és megvalósulása. Kedvező körülményként volt értékelhető, hogy az ELTE lényeges infrastruktúrabővülést nem tervezett, hiszen Lágymányoson több épülettel gazdagodott. A Gödöllői Egyetemhez való csatolás elől menekülő KÉE ismételt csatlakozásával így indultak meg a tárgyalások az ELTE és a Közgáz között.

A világ legtöbb nagy tudományegyeteme rendelkezik közgazdasági karral, az üzleti képzés pedig nagyon népszerü. Ha sikerül jól megkonstruálni a kapcsolatot a jogi karral, valamint az informatikusokkal, akkor a legjobb tudású menedzserek képezhetők. A többi társadalomtudományi területen a meglévő szervezetek erősíthetik egymást (szociológia, politológia, kommunikáció).

A vízió tehát egy - nemzetközi mércével mérve is nagy és erős, a leírt, kapcsolódó oktatási-kutatási együttmüködést megvalósító - universitas létrehozása. Ebbe az elképzelésbe a KÉE „kakukktojás”-ként szerepelt, hamarosan - ELTE kezdeményezésre - ki is szorították a csoportból. (Ennek még a végső döntési folyamatban lesz jelentősége.) Természetes része volt a víziónak az a modern universitas értelmezés is, amely infrastrukturálisan is korszerü, kiválóan felszerelt (IT, könyvtár) és hallgatóbarát egyetemet álmodott (Gólyavár felújítása, sportolási lehetőség bővítése). Mindemellett nemzetközileg is megfelelő minőségü tananyagokkal és kutatási háttérrel és az ezekhez szük- 
séges fejlesztési forrásokkal rendelkezik. Az egyesülési stratégia kidolgozására egy többszintű szervezet (koordináló bizottság, albizottságok) jött létre meglehetősen sok (kb. 50 fö), befolyásos, vagy befolyásosnak hitt vezető, vezetőoktató bevonásával. Ez a megoldás - az elképzelés szerint - már a stratégiaalkotás során kialakította volna a támogató bázist. A szakszerüség és a siker érdekében bevontuk a PwC tanácsadó céget is. A Közgázon tovább erősíthette a végső döntés sikerét az 1998 nyarán lezajlott egyetemi tanácsi szavazás eredménye. Részben a KÉE kimaradására hivatkozva ugyanis a vezetés felhatalmazást, ún. időközi szavazást kért a munka további folytatására. Ezt egy ellenszavazattal a tanács meg is adta, bár itt hangzott el először a későbbi erős érv, ha a KÉE kimaradhat, akkor nem is biztos, hogy olyan fontos és elkerülhetetlen az integráció. Az őszi szemeszter kezdetekor élénkült meg ismét az egyetemi vita részben annak is köszönhetően, hogy világossá vált, az új kormány is az integráció híve. A viták során egyre inkább hangot kaptak ellenvélemények is, elsősorban a Társadalomtudományi Kar oktatói, valamint a hallgatók részéröl, akik mellett mindig is ott álltak a „megrögzött” ellenzők. Ök voltak azok, akik semmilyen integrációt, semmilyen érdekből sem támogattak. Az egyetemi vezetés nem eléggé figyelt ezekre a „hangokra”, hiszen el volt foglalva a stratégia végső formába öntésével (450 oldal magyar és angol nyelven), amelyről novemberben végső szavazást kellett tartani. Az a széles körü kommunikáció, ami az indulást jellemezte, elgyengült, amihez hozzájárult, hogy a nyári szavazás döntő többséget jelentett a folytatásra. Ez vezetési hiba volt. Nem sikerült igazán jól a novemberi végszavazás előtti vita sem, amelynek során a vezetés nem sugárzott egyértelmü és 100\%-os elkötelezettséget az integráció elkerülhetetlensége és a javasolt stratégia szerinti megvalósítása iránt. Ezt az egyetemi tanács egyes tagjai számon is kérték azzal érvelve, hogy a KÉE kimaradhatott, most meg nincs is egyértelmü álláspont, akkor ez nem is biztos, hogy kell és nem is biztos, hogy jó. A szavazásban végül is a „nem”-ek kerültek kis többségbe, ezzel a Közgáz másodszor is nemet mondott az integrációra.

$\mathrm{Az}$ ismételt kudarc okai között megint csak erős szerepet játszott az érdekcsoportok valódi véleményének fel nem ismerése és kezelése. Az a stratégia készítése során is világos volt, hogy az integrációnak a Társadalomtudományi Kar lehet a ,vesztese”, hiszen az ELTE nagyon erős ezeken a tudományterületeken, miközben ők pl. az informatikával annyit nem nyernek, mint a menedzsment szakosok. Bár a kar képviselőit bevontuk az előkészítésbe, az ellenvéleményeket nem sikerült „leszerelni”. Hasonló módon a rajkosok mindig is az önálló Közgáz mellett voltak. Nem véletlen, hogy a szavazó egyetemi tanácsi ülésen „Tartsatok ki”! kezdetü fax keringett. Problémás volt - ahogy már említettem - a kommunikáció is, hiszen az elönyök anyagilag vitathatatlanok voltak. (Mint később kiderült évekig kellett várni az új épületre, ami óriási zsúfoltságot eredményezett az Ybl palotában.)

Az ELTE helyzete könnyebb volt. Két új karral való bővülés (a javaslat ugyanis perspektivikusan a Társadalomtudományi Kar összevonását célozta meg) nem igazán zavarja a meglévő szervezetet és érdekrendszert. A társadalomtudományi képzésben bízott saját erősségében. Végül is, ő is új, fejlesztési forrásokhoz juthatott volna. Így lett az ELTE szavazata egyértelmü ,igen”.

Láttuk, hogy a BME esetében a ,fegyelmezett lojalitás, valamint a merevebb szervezeti és müködési struktúra", mint szervezetikultúra-elemek befolyásolták a végső döntéseket. Az ELTE-vel való tárgyalások során kiderült, hogy a két intézmény ebből a szempontból sok közös vonással rendelkezik. (Jellemző példa, hogy míg a BME ragaszkodott ahhoz, hogy a hallgatói és oktatói létszám függvényében biztosítana kari képviseletet az egyetemi tanácsba, ami természetesen az ő dominanciáját eredményezte volna, addig az ELTE azonnal elfogadta, hogy minden kar azonos számú képviselővel rendelkezzen.) Az viszont, hogy a Közgáz nem szavazta meg, megint jórészt annak volt köszönhetö, hogy a vezetés nem tudta megnyerni az ellenzők „vezéreit”, az illojalitás ismét „győzedelmeskedett”. Megint csak elmondható, hogy készült stratégia, de a megvalósítás érdeke nem került többségi elfogadásra. A Közgáz - élve az egyébként nagy vonzerőt jelentő szervezeti és személyi szabadsággal - egy rövid ideig továbbra is egyedül maradt.

\section{„Amíg én miniszter vagyok a Közgáz így egyedül nem marad" - a Közgáz és az Államigazgatási Főiskola esete 1999-2000}

A címben idézett mondat az aktuális oktatási minisztertől hangzott el valamikor 1998 őszén egy rektori konferencián. Erre az időre már körvonalazódtak a nagy, integrált, vidéki városi egyetemek, Budapesten a KÉE és az ÁOE Gödöllőhöz csatolásának folyamata. Az integrációs döntések során az ELTE-hez csatoltak kisebb intézményeket. Változatlan formában müködhetett viszont tovább a Semmelweis Egyetem (SOTE), valamint a BME, amely a Közgázzal való sikertelen akció után önálló gazdálkodási kart és képzéseket alapított. A miniszteri jóslat beteljesüléseként (vagyis kifejezetten intézményeken kívüli döntések eredményeként) - különösebb indoklás nélkül - létrejött a Közgáz és az ÁIF integrációja, ami a Budapesti Közgazdaságtudományi és Államigazgatási Egyetem nevet vette fel.

Tekintettel az intézményeken kívüli döntésre, magát a stratégiai környezetet és a stratégiai menedzsment olyan elemeit, mint pl. vezetői vízió vagy lojális kultúra, nehéz lenne az előzőekhez hasonlóan elemezni. Az is lényeges, hogy ehhez a típusú integrációhoz már „,nem járt” ösztönző támogatás, még a folyamat többletköltségeit is az intézményeknek kellett kigazdálkodniuk. Tény, hogy a kormányzat elhatározta a felsőoktatás átalakítását és ezen belül, mint legfontosabb lépés, az integráció mellett döntött. A deklarációk szintjén ezzel egy hatékonyabb, a széttagolt és túlspecializált intézményrendszer helyett az universitas koncepciónak megfelelő egyetemek és föiskolák jöttek létre. Hogy mindebből mi valósult meg, nem e tanulmány szerepe értékelni. Szüken vett témánkhoz ragaszkodva kijelenthetjük, hogy ezt az integrációt nem előzte meg stratégiakészítés, hacsak a bonyolult folyamat és szabályrendszer kötelező összeállításának néhány szer- 
vezeti elemét nem tekintjük annak. Így nem beszélhettünk közös vízióról, a célokat támogató érdekcsoportokról. Világosan előkerültek azonban - pontosan a szabályozási folyamat során - a kulturális különbségek. Ezek között mindenképpen megemlítendő a tömegképzés gyakorlata az ÁIF-en, vagy olyan tradíciókhoz való ragaszkodás, amelyek még a Belügyminisztériumhoz való tartozás időszakából származtak és jelenthettek privilégiumot az intézmény számára. Ide sorolható az extra lokáció, vagy különleges vagyonelemként az uszoda az összes előnyével és veszteséges működtetésével. A bevételek több, mint 60\%-át jelentő költségtérítéses képzések más ösztönzési feltételeket jelentettek, mint a likviditási problémákból éppen hogy kilábaló Közgázon. Elég hamar megjelentek olyan humánpolitikai gondok, mint a tanári kinevezések föiskola és egyetem közötti eltérö feltételei (pl. egyetemi docens, föiskolai docens), vagy a sok apró tanszék problémája.

Szinte „minden adott volt” tehát ahhoz, hogy ne jöjjön létre tartalmi, az oktatásban és a kutatásban megjelenő integráció. A fó cél mindkét intézmény, de főleg az ÁIF részéröl, olyan szervezeti, személyi és működésbeli kontextus kialakítása és megőrzése, amelyik bármikor alkalmassá teszi a nagyobb megrázkódtatás nélküli szétválást. Jellemző példa, hogy ha nem is ezzel az elnevezéssel, de valójában önálló gazdasági igazgatóval és hozzá tartozó apparátussal rendelkeztek, vagy az egyetlen összevont szervezetet, a Testnevelés Tanszéket a belső torzsalkodások miatt ismét szét kellett választani. A sors iróniája, hogy az együtt töltött valamivel több, mint egy évtized során jelentősen enyhültek ezek a merev, különállási törekvések. Az egykori ÁIF elfogadottságában is egyetemi karrá (Közigazgatástudományi Kar) fejlödött. A Corvinus név jelentős vonzerőt jelentett a hallgatóság irányából, sikerült olyan infrastruktúra-fejlesztéseket megvalósítani, amelyek finanszírozása egykori Közgáz épületek eladásából, vagy más közös projektekből valósult meg. Egy jelentős TÁMOP-pályázat keretén belül jelentős lépések történtek a közös kutatások irányába is. Ezek azonban már senkit nem érdekeltek az ismételt kormányzati döntés meghozatalakor, amikor ugyanis 2011-ben az egykor Közgázhoz csatolt kar elkerült a Corvinusról és a mai napig a Nemzeti Közszolgálati Egyetem ,zászlóshajója”. Az alakuláskor el nem készült, de a fejekben „meglévő stratégia”, az önállóság maximalizálása „meghozta gyümölcsét”, a szétválás nem okozott túl nagy gondot, és lényegében egyetlen hang nélkül (beleértve az egyhónapos Közszolgálati Egyetem diplomáját kapó hallgatókat is) ment végbe.

\section{Végre egy önkéntes integráció! A Közgáz és a KÉE esete 2003-2004}

A 2000-ben létrejött integrációk müködési tapasztalatai egy-két év után kezdtek érzékelhetőbbé válni. A Gellérthegy lábánál, a Villányi úti 8 hektáros arborétumban elhelyezkedő Kertészeti és Élelmiszertudományi Egyetem „nem tudta megszokni” a Szent István Egyetemmel való kényszerházasságát. Részben „elnyomottnak” érezte magát, a bürokráciába való bekapcsolódás a távolság miatt nehézkesen ment, de a legerősebb érvet az egyre erősödő kilépési szándék mellett a Gödöllőre való kiköltöztetés „réme” jelentette, ami egy másfél évszázados tradíció megszünését is jelentette volna. Az elsődleges cél az ismételt önállóvá válás volt, amit a kormányzat kifejezetten elutasított.

A Duna másik partján, szintén szuper környezetben, de még mindig a visszaadott Lónyai Gimnázium helyettesítéséért „küzdő” Közgáz, az aktuális felsőoktatási törvényből fakadóan, ideiglenes akkreditációval rendelkezett, mivel csak egy tudományterületen müködött. Így, természetesen személyi kapcsolatok „közvetítésével” talált egymásra a két intézmény. A fó motívumok - az elözőekből levezethetően - a következők voltak:

- a Közgáz nem igazán fenyegethette átköltöztetéssel az arborétum lakóit, a legfőbb veszély tehát „elhárítva",

- a múvelt tudományterületek nem fonódnak annyira össze, hogy bármelyik oldalon reális veszélyként kellene fajsúlyos összevonásokkal számolni,

- vannak ugyanakkor olyan, a nemzetközi és hazai tudományos és oktatási világban gyorsan fejlödő területek, amelyeknek magas fokú müvelése mindkét intézményben folyik, és egyesített erővel jelentős szinergiák érhetők el; tartalmilag tehát a vízió a több tudományterületen (így a törvénynek megfelelően) működő, a környezettudományban, az informatikában és esetleg bizonyos menedzsmenttárgyak oktatásában együttműködő egyetem képét vetítette előre,

- ki nem mondott, talán a kezdet kezdetén fel sem ismert, de a későbbi együttmüködés során nagyon erősen ható, ún. kölcsönös elönyt jelentett a 2004 szeptemberétől bevezetett Corvinus brand, amely a KÉE irányában történő jelentkezéseket is érzékelhetően megnövelte; a másik oldalon viszont a természettudományi normatívából, valamint különböző programfinanszírozásokból költségvetési többlettel rendelkező Villányi úti karok hosszabb ideig biztosították az egyetem likviditását,

- mindezeken túl, a már egyesített intézménynek hosszú folyamat után - sikerült átíratni az egykori KÉE vagyont a Corvinusra, és felvetődött annak a stratégiai lehetősége, hogy, azok értékesítéséből származó bevétel felhasználható a leromlott épületállomány rekonstrukciójára.

Adottak tehát a motivációk, a valós, vagy vélt célok, és úgy tünt, hogy a stakeholderek érdekei is egy irányba mutatnak mindkét oldalon. Az integráció előkészítését egy szük körű csapat végezte. Formális stratégia nem készült, az előzőekben megfogalmazottak egy részét néhány oldalas előterjesztésben írták le. Szó sem volt széles körü vitáról. Az akkori vezetéshez viszont lojális egyetemi tanács megszavazta az egyesülést. A BME-t és az ELTE-t elutasító Közgáz vezetése és vezető fórumai a három kísérlet közül talán a legkevésbé indokolható megoldásra szavaztak igennel. Ahogy az előzőek kudarca, leszavazása, jelentős mértékben a stratégia nem megfelelő menedzselésén, úgy 
az igen döntés is a vezetésen múlt. A vezetésen, amelyhez lojális volt a Közgáz és vastag dokumentumok, hónapokig tartó viták nélkül is elfogadta annak javaslatát. 2003. szeptember 1-jével egyesült a két egyetem és egy év múlva a 2004. szeptember 9-én megtartott tanévnyitó ünnepség keretében ,vette fel” a Budapesti Corvinus Egyetem nevet.

Az integráció tehát szűk körben elökészített, formálisan nem minden elemében kidolgozott stratégia mentén létrejött, így ez az az eset, amelynél maga a megvalósulás és az annak során tesztelhető stratégiai menedzsmentrendszer elemeinek az alkalmazása elemezhető. Mielőtt ebbe belemennénk, rögzítsük a végeredményt: a Közgáz KÉE integráció valamivel több, mint 11 évig élt (csaknem azonos időtartammal, mint a Közgáz-ÁIF közös szervezete). 2015 januárjától az önkéntes alapon létrejött egyesülés kormányzati döntéssel, nem mindenki akaratával megegyezően szünt meg, és a KÉE karok visszakerültek a Szent István Egyetem szervezetébe, a Corvinus utódja pedig az egykori Közgáznak megfelelö három kar lett. Ezen végeredménnyel kapcsolatban egy sor kérdés tehető fel:

- Eleve rossz volt-e a Közgáz vezetésének stratégiája és/vagy az integráció nem volt megfelelően előkészítve? Nem váltak világossá még a döntés előtt a két intézmény közötti különbségek a szervezeti kultúrában, a KÉE karai közötti belső viták rejtve maradtak, mint ahogy az is, hogy belső integrációra sem hajlandóak, nemhogy más egyetem tanszékével (ld. szőlész-borász tanszékek összevonása, a nyelvi képzés körüli belső viták stb.)?

- Vajon a meg nem valósított - Mintzberg szóhasználatában realizált stratégia, pontosabban a szándékolt és realizált - stratégia különbsége vezetett-e a szétválasztáshoz? Pragmatikusan fogalmazva a meg nem valósított szervezeti integráció (új környezettudományi kar nem alakult meg, párhuzamos struktúrák maradtak, olyan területeken, mint a nyelvoktatás, testnevelés, matematika-informatika, bizonyos menedzsmentdiszciplínák pl. marketing), adott érveket a kormányzat kezébe a változtatásra?

- Vajon a stakeholderek mindegyike akarta az integrációt? Mi a magyarázata, hogy a szétválasztás elleni megmozdulásokon a pesti oldalról (Közgáz) jóformán senki nem vett részt?

- Talán a legfontosabb lenne azt tudni, hogy érdemes-e az okokat a Corvinus Egyetemen belül keresni? Nem ott van-e az igazság, hogy ez a kormányzati döntés egyik, az új felsőoktatási stratégia megvalósításának bizonyítékaként szerepelt, és az összes többi tényező nem okként, hanem megkönnyítő magyarázatként jött számításba?

E tanulmány szerzője erősen hajlik ezen utolsó kérdésben megfogalmazott állítás elfogadására. Ezzel együtt az is kijelenthető, hogy e vélemény erősen szubjektív, hiszen a dezintegráció 8 év vezetői munka erőfeszítéseit, pontosabban annak eredményeit tette semmissé. A név ugyanis megmaradt, de az eredeti Corvinus Egyetem, amilyennek a 2004. szeptember 9-i évnyitón megálmodtuk, eltűnt. Az erős szubjektivitást „indokolja” az is, hogy a nem megfelelő stratégia és/vagy a jó elképzelések nem megfelelő menedzselése és megvalósulása vitán felül állóan a vezetés felelőssége. E tényezőket nem figyelmen kívül hagyva kísérlem meg a válaszadást a feltett kérdésekre.

Az eredeti, még 2003-ban kidolgozott döntés-elökészítő dokumentum (nevezzük stratégiának), de sokkal inkább a formális vagy informális tárgyalások megállapodásai jó célokat, megvalósitható célokat fogalmaztak meg. Az aktuális környezeti tényezők inkább kedveztek az eltervezett szervezeti változásnak semmint akadályokat gördítettek volna elé. Tény, hogy ilyen típusú integrációt ebben a periódusban már külön összeggel nem finanszírozott a kormány, de a közeli EU-s tagság és a ppp (public-private-partnership) projektkilátások ilyen oldalról is reményt keltőek voltak.

Kijelenthetjük, hogy a legfontosabb érdekcsoportok támogatták a döntést. Mindenképpen így volt ez a formális testületek esetében, de nem igazán volt érzékelhető informális ellenállás vagy „szervezkedés” sem. Két dolgot érdemes ezzel kapcsolatban megjegyezni. Egyrészt a vízió, a célok - az adott fázisban és szinten - nem sértettek érdekeket. Az általánosan megfogalmazott integrációs lépések részben tartalmilag is indokoltnak tüntek (pl. környezettudományi együttmüködés), vagy esetleges jövőbeni ,veszélyüket" elnyomta a SZIE-ről való eljövetel lehetöségének eufóriája. Akkor úgy tűnt, hogy a hallgatóságot és a „mindennapi” munkavállalókat kevésbé érinti a változás, és kormányzati oldalról is az lehetett a vélemény, hogy jó, ha önkéntesen megoldódik egy konfliktusforrás a felsőoktatáson belül. Az érintetti körrel kapcsolatban viszont egy felsőoktatási specialitás ma már eléggé világosan körvonalazható, és ez nem más, mint a folyamatos vezetőváltás. ${ }^{8}$ A folyamatosság nemcsak az első számú vezető egy vagy két periódus utáni váltását, de a többiek (rektorhelyettesek, dékánok) rektori periódusokon belüli cseréjét is jelenti. Ez a tényező egy rektori perióduson belül is nehezíti a stratégia megvalósítását, de ha netán hosszabb távú, rektori periódusokon is átívelő célokról és akciórendszerről van szó, akkor a nehézség fokozódik. Amennyiben kormányváltás(ok) is színezi(k) a helyzetet új felsőoktatási stratégiával, akkor még kevésbé csodálkozhatunk azon, hogy a 2003-ban elképzelt új, közös egyetem stratégiája, azaz a szándékolt stratégia, tíz év alatt másképpen valósul meg (realizált stratégia), vagy 2014-ben ellenkező irányba módosul. Ez alatt az időszak alatt ugyanis 3 rektor, 10 rektorhelyettes és több, mint 20 dékán váltotta egymást ( 7 kar esetében ez igencsak 3 vezető karonként), értelemszerűen nem teljesen azonos elképzelésekkel, érdekháttérrel, vezetői habitussal és lojalitással.

A megvalósítás során tehát ez mindenképpen figyelembe veendő körülmény, de nemcsak ennek tudható be, hogy a szétválasztás szinte fő okaként a meg nem valósult integrációt deklarálták. Egyes kritikusok odáig mentek, hogy kijelentették, hogy olyan mértékü szervezeti összevonásokra lett volna szükség, amely következtében nem nyílt volna lehetőség az egyszerü szétválásra. (Nota bene, ezt az Államigazgatási Főiskola vonatkozásában is, mint elszalasztott megoldást jegyezték.) A tény az, hogy az in- 
tegrációt követő egyetemi vezetés az immár hétkarú, és igencsak különböző tudományterületeken oktató-kutató intézményben a minél jobb feltételrendszer (infrastruktúra, munkahelyi közérzet stb.) megteremtését és az öszszegyetemi presztízs növelését tartotta elsődleges feladatának, a fö tevékenységek és a kapcsolódó gazdálkodás területén a decentralizált (kari) irányítást preferálta. Ennek megfelelően az integrálódás teljes mértékben megvalósult az egyetemi felső szintű irányítás és igazgatási funkciók, valamint szervezetileg jelentős mértékben a gazdálkodás, vagyongazdálkodás-fejlesztés területén. A stratégia e legfontosabb eleme nem realizálódott az oktatásban - sem tartalmi, sem szervezeti szinten - és kezdeti eredményekről lehetett beszélni a kutatásban, döntően a TÁMOP-projekt kapcsán. Az okokat elemezve kijelenthetjük, hogy az elképzelt környezettudományi szervezeten (kar) kívül, amely, ha a KÉE kampusz keretében jött volna létre, és így a Közgáz érdekeivel „ellenkezett”, minden más integrációt - tegyük hozzá logikusan - a Közgáz dominált volna, ami a másik oldalról kérdőjelezi meg a támogatást (nyelvi intézet, matematikai intézet stb.). Erősen szerepet játszott a kudarcba fulladt integrációs kísérletekben a KÉE tradíciókhoz ragaszkodó szervezeti kultúrája, és azok a belső konfliktusok, amelyek az eredeti döntési folyamat során nem voltak érzékelhetők. Jól példázza ezt, hogy a legtermészetesebb szervezeti változás, az eredetileg két külön karhoz tartozó szőlész, illetve borász tanszékek egy intézet alá rendelése lényegében ,passzív ellenállást” váltott ki sok-sok millió forintos veszteséget okozva a hatékonyság növelése helyett. Ide sorolhatók a testnevelési és nyelvi képzés körüli folyamatos költségvetési viták. Sem a két korábbi egyetem szervezeteinek összevonása, sem a belső szervezeti változások nem voltak sikeresek.

Mindehhez tegyünk hozzá még két dolgot. Egyrészt a két egyetem eltérő tudományterületeken való müködése mind az oktatás, mind a kutatás területén oly mértékben különbözött, hogy az alaptevékenységekben fel sem merülhetett az integráció, az átoktatás, a közös kutatás kérdése. Ettől még müködhetett volna itthon is és külföldön is sikeresen a Corvinus Egyetem. Másrészt nem kerülendő meg, hogy bizonyos területeken, határozottabb vezetői fellépéssel és szervezeti és személyi támogatás megszerzésével talán lehetett volna az összegyetemi, és elsősorban a hallgatói érdekeknek megfelelő változásokat elérni. A menedzsment, a marketing és a számvitel oktatása mindenképpen ezek közé sorolandó.

Mindezek ellenére kijelenthetjük, hogy a „közös” egyetem az első négy éves müködési időszakát megélve, jól müködött. Ezt az is bizonyítja többek között, hogy zökkenőmentesen bevezették a Bologna-rendszert, amelyben a Corvinus karok országosan irányító szerepet vállaltak.

A Corvinus ,,brand name"-et gyorsan megismerésre és elfogadásra került itthon és külföldön, és mindenki érezte ennek jótékony következményeit a hazai felsőoktatási rangsorokban és a kiemelkedö létszámú hallgatói jelentkezésekben, a nagyon magas bekerülési pontszámokban. A Közgáz felavatta új épületét a még az előző vezetés által megvásárolt telken, és komoly kollégiumi és más infrastrukturális rekonstrukciókat (főépület, a Villányi úton új könyvtár) valósítottak és terveztek meg. A viszonylag konszolidált költségvetési helyzet oktatást, kutatást ösztönző javadalmazási megoldások bevezetését is lehetővé tette. A pozitív perspektívát tovább erősítették a 2008-2010-es években elnyert díjak (Minőségi Díj, Kiváló Egyetem) és pályázati projektek (TÁMOP, energetikai pályázat, doktori képzés fejlesztése stb.), amelyek nagyon jelentős kutatási és oktatási infrastruktúra-fejlesztést (müszerek, laborok) tettek lehetővé a Villányi úti campuson, és több, kiemelt kutatás indítását a Közgázon és az ÁIF-en. Ezek keretén belül megjelentek közös alprojektek is, ami az integráció egy magasabb szintjének irányába mutatott.

A felsorolt eredmények fontos következménye volt az egységes egyetem iránti bizalom erősödése, míg a másik oldalról kijelenthetjük, hogy „el is fedték” a költségvetési gazdálkodás nem teljesen megszilárdult fegyelmét és az egykoron többlettel rendelkező Villányi úti karok egyike-másika kezdett „,veszteséget termelni”. Aki tehát a jó, szándékolt stratégia meg nem valósulását, mint a Corvinus Egyetem szétdarabolásának alapvető okát jeleníti meg, az nincs teljesen tisztában az egykori helyzettel, miközben véleménye részigazságot tartalmaz. Ez utóbbiak kevésbé erősek az ÁIF esetében, amikor is a kormányt a Nemzeti Közszolgálati Egyetem megalapításától aligha tántoríthatta volna el egy-két jogi vagy szervezési tanszék összevonása. A KÉE esetében már megfontolandóbb érvekként is „előhúzhatók”, ha - szerintem - nem is döntő tényezőként.

Visszatérve a ,stakeholderek” támogatására, érdemes felhívni a figyelmet arra, hogy több tényező eredőjeként (személyi változások, hallgatói jelentkezések, egyes egységek gazdálkodási problémái és veszteséges müködése) a két campus között apadó bizalom és egyre több konfliktus jelent meg, egyre többször kapott hangot a Közgáz (elsősorban a „pénztermelő” Gazdálkodástudományi Kar) részéröl az átfinanszírozás érdektelensége, megjelentek egyes kinevezések körüli viták és más ellentétek. A költségvetési elvonás, majd/és a gazdasági föigazgató egyetem ellenére történő kinevezése és az ebből fakadó súlyos vezetési és likviditási problémák tovább élezték az amúgy sem harmonikus együttmüködést. Az induláskori elképzeléseket a későbbi eredményeket elhomályosították a mindennapok konfliktusai, amelyek következtében meghatározó Közgáz egyéniségek és a mögéjük állt szervezetek nyilvánították ki véleményüket a nem kívánt integrációról. Mindez még mindig kevés lett volna a szétválasztáshoz (hiszen ne feledjük, hosszú éveken keresztül, kormányoktól függetlenül az integrációé, az universitas koncepcióé volt a föszerep), ha nem ebben az időben jelenik meg az új felsőoktatási stratégia, amely - ha nem is teljesen explicit módon, de az azóta meghozott döntések egyike másikából kikövetkeztethetően - a szakegyetemek irányába kívánta elmozdítani az intézményrendszert (pl. az egy, nagy agráregyetem gondolata). Nota bene egy stratégia végrehajtása nem történhet meg szervezeti változások nélkül. Értelemszerüen „terepet kellett keresni” mindkét egymással összefüggő célnak. Nagyon eltérő profil, nem elégséges integráció, erős és önmagukban nagyon versenyképes Közgáz karok (az egy tudományterület már nem volt érdekes), ráadásul a szétválás belső (Köz- 
gáz részéröl ${ }^{9}$ ) támogatása ,tálcán kínálta” a „,öbb legyet egy csapásra" megoldást. Ez a válasz arra a kérdésre, hogy miért is nem csatlakoztak a pesti oldal egyetemi polgárai a KÉE által szervezett demonstrációkhoz. E demonstrációk, amelyeket megelőztek bizonyos, de elkésett integrációs vállalások, amelyek határozottan a további együttmaradás mellett szóltak, ugyan kifejezésre juttatták a Villányi úti egyetemi polgárok érdekeit, nem tudták meggyőzni a kormányzatot. Szinte egyenes út vezetett 2015. január 2-ához a kibővült Szent István Egyetemhez és a három karrá „fogyatkozott", és a Budapesti Corvinus Egyetem nevet megtartó Közgázhoz.

Ezzel a Közgáz-integrációk története - remélhetőleg hosszabb időre - lezárult, miközben maga az intézmény minden területén jól teljesít. Arra már nem kaphatunk választ, hogy hogyan alakult volna a hat- vagy hétkarú Corvinus sorsa, mint ahogy nem ismert az egykori KÉE karok helyzete, perspektívái sem a Szent István Egyetem keretében.

\section{Következtetések}

A tárgyalt esetek (föleg Közgáz BME és Közgáz ELTE) ékesen bizonyítják azt az általánosan is érvényes tételt, hogy nem elég jó (vezetés szemszögéből) stratégiával rendelkezni, azt el is kell tudni fogadtatni, sőt a döntés megvalósításához szükség van olyan személyi, szervezeti, motívációs és kulturális háttér kialakítására, amely támogatja azt.

Mindegyik fázisban szükség van a stakeholderek hatalmi és érdekviszonyainak figyelembevételére. E tekintetben nemcsak a formális hatalmi struktúrák szerepe, de - ahogy az a példákból is kitünt - az informális szervezeti és személyi konstelláció befolyása is lehet meghatározó.

A szervezeti kultúra több szálon is szerepet játszik mind a stratégia-alkotás, a döntéshozatal és a megvalósítás során. Tanulmányunkban részben az integrálódni kívánt (külső és/vagy belső, önkéntes döntés nyomán) szervezetek kulturális vonzerejének (vagy éppen taszító jellegének) a szerepét emeltük ki, de még hangsúlyosabban a vezetés iránti szervezeti lojalitás, a döntési folyamat hierarchikusabb, vagy demokratikusabb oldalát, mint az elfogadás során meghatározó tényezőket hangsúlyoztuk.

Hozzá kell mindehhez tenni, hogy az érdekek felismerése nem minden esetben evidens. A stratégiának fontos funkciója lenne megmagyarázni és meggyőzni az ellenzőket arról, hogy a megvalósítás milyen előnyökkel jár. Eseteink világosan példázzák, hogy az elfogadtatás kudarcai jórészt a meggyőzés elkerülésére, vagy nem megfelelö módjára vezethetők vissza.

Úgy tünik maga a stratégiaalkotás szervezeti megoldása - széles kör - szakértők bevonása, fórumok, viták ugyan segítik, de nem meghatározók a döntés szempontjából.

Talán felsőoktatási specialitásnak lehet tekinteni a törvényből következő, folyamatos vezetőváltást. Ez egyik oldalról jó és kívánatos, a másik oldalról a stratégiai menedzsment elméleti követelményeit tekintve hátrányokkal is jár:
- eseteink is bizonyítják, hogy az új, elsőszámú vezetô általában új, de minimum ,újított” stratégiával áll elő; ha ez a környezeti változáshoz való igazodást jelenti még nem jelent problémát, a legtöbbször azonban a kidolgozott és elfogadott stratégia kifutása (megvalósítása) elött történik meg az új megjelenése, vagy olyan belső körülmények megváltoztatása, amelyik már nem teszi lehetővé a realizálást, és/vagy

- meglehetősen nehéz biztosítani, hogy ugyanaz a „,csapat" hajtsa végre a stratégiát, amelyik kidolgozta és elfogadta. Így a megvalósítás során már nem érvényesül az ,alkotás eufóriája”, sőt, sokkal gyakoribb az elődök (jogos vagy jogtalan) kritikai értékelése, mint az ö elképzeléseiknek a továbbvitele.

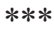

Bár a magyar felsőoktatás az elmúlt két évtized hektikussága után stabilitásra vágyik, minden bizonnyal a jövőben is lesznek változások az intézményi struktúrában. A Közgáz eseteinek tanulságai talán segíthetnek a progresszív irányok megválasztásában.

\section{Jegyzetek}

1 Ld. Chandler, 1962; Ansoff, 1965; Learned - Christensen - Andrews - Guth (a Harvard iskola képviselöi) 1965

2 A tanulmány a folyóirat megjelenésének 40. évfordulójához kapcsolódóan dolgozta fel és elemezte a négy évtized cikkeinek absztraktjait.

3 A „Közgáz” megnevezés részben elfogadott a közvéleményben, másrészt alkalmazása elkerülhetővé teszi az adott időszakban aktuális név használatát és magyarázatát.

4 A tényekhez hozzátartozik, de témánk szempontjából nem releváns, hogy rövid ideig müködött a Főiskolai és a Posztgraduális Kar is 1989 után.

5 Nyugodtan használhatjuk ezt a kifejezést, hiszen a Közgáz elődje a József Nádor Müszaki és Gazdaságtudományi Egyetem Gazdaságtudományi Kara volt 1920-tól.

$6 \mathrm{Ez}$ az elképzelés nem szorította volna háttérbe a többi kart, de az együttmüködési súlypontok kétségtelenül az említett tudományterületekre koncentrálódtak volna.

7 Legalább egy lábjegyzetben rá kell mutatni arra, hogy a hallgatói véleményeket általában, de az egyetemi tanácsban személyesen is jelentősen befolyásolták az elit Rajk Szakkollégium tagjai, amelynek vezetése is az integráció ellen lépett fel. Ez a kép hủen tükrözi a formális és informális hatalmi struktúra helyzetét és hatásait a 90-es évek közepének Közgázán.

8 Természetesen megjelenik ez más területeken is, de a felsőoktatásban ez kötelező.

9 Megjegyzendő, hogy a rektor nem támogatta a döntést, de a szenátusi titkos szavazás igen.

\section{Felhasznált irodalom}

Ansoff, I. (1965): Corporate Strategy. New York: McGraw Hill

Barakonyi Károly (szerk) (2009): Bologna Hungaricum: Diagnózis és terápia. Szentendre: Új Mandátum Könyvkiadó

Bhatia, V. K. (2014): Strategic Management - History and Development, http:vijaykumarbhatia.weebly.com/strategic-management-history-a ... letöltve 2014. 01. 14. $12: 16$

Berács József et al. (2017): Magyar Felsőoktatás: Stratégiai helyzetértékelés. Nemzetközi Felsőoktatási Kutatások Központja ISSN 2064-7654. 
Chandler, A. (1962): Strategy and Structure: Chapters in History of the American Industrial Enterprise. Cambridge, MA.: M.I.T. Press

Chikán, A. (2008): Vállalatgazdaságtan. 4. átdolgozott, bővített kiadás. Budapest: AULA Kiadó

Cummings, S. - Daellenbach, U. (2009): A Guide to the Future of Strategy? The History of Long Range Planning. Long Range Planning, vol. 42., p. 234-263.

Grant, R. (2008): Contemporary Strategy Analysis. Oxford: Blackwell Publishing

Hermann, P. (2005): Evolution of Strategic Management: The Need for New Dominant Design. International Journal of Management Reviews, vol. 7. issue 2., p. 111-130.

Hrubos Ildikó (2013): Globalizáció - informatikai forradalom - akadémiai értékek. Educatio, 22: (3), p. 311-322.

Lapersonne, A. - Sanghavi, N. - De Mattos, C. (2015): Hybrid Strategy, Ambidexterity and Environment: Toward an Integrated Typology. Universal Journal of Management, 3(12), p. 497-508.

McGrath, R. (2013): Transient Advantage. Harvard Business Review, June. p. 61-70.

Mintzberg, H. - Ahlstrand, B. - Lampel, J. (1998): Strategy Safari - A Guided Tour Through the Wilds of Strategic Management: Harlow: Prentice Hall Europe (magyarul megjelent: Stratégiai Szafari, HVG Kiadó Rt. Budapest, 2005)

Mintzberg, H. - Rose, J. (2003): Strategic Management Upside Down: Tracking Strategies at Mc. Gill University from 1829 to 1980. Canadian Journal of Administrative Sciences, Dec. Vol. 20 Issue 4, p. 270-290.

O'Shanassy, T. (1999): Lessons from the Evolution of the Strategy Paradigm. Working Paper. RMIT Business, Nov

Polonyi István (2015): A hazai felsőoktatáspolitika átalakulásai. Iskolakultúra, 5-6., p. 3-14.

Porter, M. - Kramer, M. (2006): Strategy and Society: The Link Between Competitive Advantage and Corporate
Social Responsibility. Harvard Business Review, Dec., p. 78-92.

Porter, M. - Kramer, M. (2011): Creating Shared Value: How to Reinvent Capitalism - and Unleash a Wave of Innovation and Growth. Harvard Business Review, Jan - Febr., p. 1-16.

Porter, M. - Reinhardt, F. (2007): Strategic Approach to Climate. Harvard Business Review, 85. no. 10. (October), p. 22-26.

Porter, M. (1980): Competitive Strategy: Techniques for Analysing Industries and Compatitors. New York: Free Press

Porter, M. (2001/b): Strategy and the Internet. Harvard Business Review, March, p. 63-79.

Rumelt, P. R. (1984): Toward a Strategic Theory of the Firm. in: Lamb, R. (ed.): Competitive Strategic Management. Englewood Cliffs, NJ: Prentice Hall, p. 556570.

Spanos, Y. E. - Lioukas, S. (2001): An examination into the casual logic of rent generation: Contrasting Porter's competitive strategy framework and the resource-based perspective. Strategic Management Journal, vol. 22., p. 907-934.

Tari, E. (1996): A stratégiai menedzsment elméletének és gyakorlatának fejlődéstörténete a piacgazdaságokban. in: Antal-Mokos, Z. - Balaton, K. - Tari, E. - Drótos, Gy. (1996): Fejezetek a stratégiai menedzsment témaköréből egyetemi jegyzet. Budapest: Budapesti Közgazdaságtudományi Egyetem, p. 1-33.

Taylor, B. (1986): Corporate Planning for the 1990s: The New Frontiers. Long Range Planning, 6., p. 13-18.

Teece, J. D. (1980): Economies of the Scope of the Enterprise, Journal of Economic Behaviour and Organisation, 1., p. 223-247.

Temesi József (szerk) (2012): Felsőoktatás finanszírozás: Nemzetközi tendenciák és hazai helyzet. Budapest: AULA Kiadó 